\title{
O PNPG 2011-2020: OS DESAFIOS DO PAÍS E O SISTEMA NACIONAL DE PÓS-GRADUAÇÃO'
}

\author{
Francisco César de Sá Barreto* \\ Ivan Domingues** \\ "O que fazemos, isso somos, nada mais" \\ Pe. António Vieira
}

RESUMO: $\mathrm{O}$ artigo tem por objetivo esclarecer a comunidade acadêmica ligada à pós-graduação sobre os fundamentos e as diretrizes do PNPG 2011-2020 que acaba de ser publicado pela CAPES. Para tanto, procura-se contextualizar o novo Plano no quadro histórico mais amplo dos Planos anteriores, bem como no tempo presente e na conjuntura atual do país, com seus megadesafios, os grandes legados históricos, os problemas seculares do sistema de ensino e os caminhos para superá-los. Junto com as informações e os esclarecimentos, o leitor encontrará um conjunto de questionamentos e análises teórico-conceituais sobre os rumos da ciência e tecnologia em nosso país e seus impactos sobre o sistema de pós-graduação, considerando as demandas, os gaps e as maneiras de processá-las e vencê-los. Palavras-chave: Plano Nacional de Pós-Graduação; CAPES; Contexto; Desafios; Recomendações.

\section{1-2020 'NPGS': THE COUNTRY'S CHALLENGES AND THE NATIONAL PLAN OF GRADUATE STUDIES}

ABSTRACT: This article aims to illuminate the foundations and policies of the 'NPGS' 2011-20, which has just been published by CAPES, to the academic community linked to the Brazilian graduate system. To this end, the new Plan is contextualized in the broader historical scene that comprises the previous Plans, as well as in the present conjuncture of the Nation, with its mega-challenges, great historical legacies, and enduring problems of the educational system and the ways to overcome them. Along with the information and clarification, the reader will find a set of questions and a theoretical-conceptual analysis of the science and technology courses in our country and their impact on the graduate system, considering the demands, gaps and ways they can be processed and overcome.

Keywords: National Plan of Graduate Studies; CAPES; Context; Challenges; Recommendations.

\footnotetext{
*Doutor em Física pela University of Pittsburgh, Pittsburgh, EUA, Estados Unidos; Professor Emérito da Universidade Federal de Minas Gerais (UFMG); Professor Visitante da Universidade Federal de São João Del Rei (UFSJ). E-mail: fcsabarreto@gmail.com ** Doutor em Filosofia pela Université de Paris I (Panthéon - Sorbonne); Professor Titular da Universidade Federal de Minas Gerais (UFMG); Bolsista de Produtividade 1A do Conselho Nacional de Desenvolvimento Científico e Tecnológico (CNPq). E-mail: domingues.ivan3@gmail.com
} 


\section{INTRODUCุÃO}

Tendo participado ativamente da elaboração do Plano Nacional de Pós-Graduação 2011-2020, num processo longo e complexo que durou mais de seis meses, procuraremos agora nos distanciar do que foi feito e avaliar criticamente o processo e emitir nossa opinião num plano mais pessoal. Trata-se, pois, de um esforço intelectual para encontrar as ferramentas analíticas que possibilitem demarcar um espaço capaz de abrigar e tornar coerentes duas exigências: o ponto de vista do Colegiado do qual fizemos parte e que resultou num documento público impessoal e sem autoria individual; a perspectiva de dois indivíduos agora desobrigados do Colegiado, a um tempo solidários do que foi realizado e veio a lume, e assumindo os riscos de uma autoria não só pública e assinada, mas dividida ou compartilhada. Por isso, salvo as remissões diretas ao Plano e as citações que o leitor encontrará nas páginas que seguem, tudo o mais que encontrar será de nossa responsabilidade, e não deverá ser transferido a terceiros ou à direção da CAPES. À diferença do documento de referência, oficial e matéria de política pública, o que se oferece ao público agora é um artigo acadêmico, e como tal - esperamos nós - há que ser recebido e escrutinado.

Antes de mais nada, é preciso fornecer um breve histórico do Plano para que o leitor se situe e se veja minimamente informado. Primeiro, este é o sexto de uma série iniciada nos anos setenta, tendo como abrangência o quadriênio 1975-1979. Segundo, o Plano é uma matéria de política de governo, como assinalado, tendo como órgão responsável a CAPES, agência conhecida de todos nós, fundada em 1951 e tendo celebrado há pouco seus 60 anos. Terceiro, o Plano é parte do Plano Nacional de Educação, de responsabilidade do MEC e de cuja estrutura a CAPES integra, devendo em princípio estar coordenado ao instrumento maior que visa o sistema de educação como um todo. Quarto, o escopo do Plano é virtualmente todo o conjunto do sistema nacional de pós-graduação (daqui para a frente SNPG), abrangendo as instituições federais de ensino superior (IFES), bem como as públicas estaduais e municipais, além das privadas, confessionais e comunitárias. Quinto, à exceção dos programas de pós-graduação da USP e de Faculdades isoladas das IFES, como medicina e direito, que têm uma antiguidade maior, o SNPG foi criado há cerca de quarenta anos, especialmente nos anos 70, tendo sido o primeiro Plano implantado um pouco depois, 
quando os números eram acanhados e o país tinha um mundo a ganhar. Estes são em grandes linhas os grandes acontecimentos que povoaram a nossa pós-graduação e tais são seus atores mais conhecidos, com a CAPES e o sistema de avaliação à frente. Falta, porém, dar ao leitor uma ideia dos cinco planos anteriores, com suas ênfases, seus propósitos e suas principais realizações, proporcionando-lhe o quadro comparativo mais amplo com cuja ajuda poderá apreciar as novidades, as ênfases e os objetivos do novo. Assim, como salienta a Introdução do PNPG 2011-2020, o primeiro plano (1975-1979)

[...] teve como missão principal introduzir o princípio do planejamento estatal das atividades da pós-graduação, então recentemente implantada em âmbito federal, integrando-as na graduação e fomentando a pesquisa, com o objetivo de formar especialistas - docentes, pesquisadores e quadros técnicos - para o sistema universitário, o setor público e o segmento industrial ${ }^{2}$.

O contexto é o regime militar e o projeto desenvolvimentista que o acompanhou, ao lado da dura repressão que atingiu as universidades no mesmo período, gerando a situação ambivalente, para não dizer esquizofrênica, em que o professor como classe era reprimido enquanto cidadão e convocado a colaborar com o Estado enquanto acadêmico ou cientista. Por seu turno, os fundamentos institucionais junto com os marcos legais foram estabelecidos anos antes, com a reforma universitária de 1968, que instituiu os Departamentos e acabou com as cátedras. Já os agentes que protagonizaram a mudança - mudança tardia, diga-se de passagem, a julgar pela Europa e a América do Norte, que implantaram o doutorado e a pesquisa universitária séculos antes -, e que em nosso país foi vista como uma verdadeira revolução na pesquisa científica e no ensino superior, foram o CNPq e a CAPES, ambos criados em 1951.

Em seguida, com um interregno de três anos, foi a vez do segundo plano, com outras características e o período 1982-1985 como horizonte. O contexto é o fim do regime militar, e de acordo com a Introdução supracitada não levará a mudança de vulto no sistema, uma vez que

[...] mantém as ênfases do plano anterior, e acrescenta-lhes o crivo da qualidade nas atividades da pós-graduação, tendo como instrumento a avaliação, que já existia em estado embrionário desde 1976 e que será então aperfeiçoada e institucionalizada $[\ldots]^{3}$. 
Sabe-se que a avaliação é sem dúvida um capítulo importante no grande livro da pós-graduação e voltaremos a ele mais de uma vez ao longo do artigo.

Por sua vez, o terceiro plano (1986-1989) como salienta a Introdução irá “[...] sofrer os influxos da época e do ambiente político (Nova República) [...]” e tratará de subordinar “[...] as atividades da pós-graduação ao desenvolvimento econômico do país, mediante a integração das atividades ao sistema nacional de ciência e de tecnologia [...]"4. Trata-se da época do governo Sarney e como tal marcado por duas características: no âmbito político, a implantação da Nova República e da nova Constituição (1988), levando a nação a vencer o trauma da morte de seu primeiro presidente, terminado o regime militar; no âmbito econômico, as crises internas e externas, conduzindo aos planos Cruzado, Bresser e Verão, planos que não deram certo e crises que atingiram as universidades, devido à inflação estratosférica que corroía os investimentos em pesquisa e pós-graduação, ao mesmo tempo que depreciava os salários, causando grande insegurança. Em consequência, os céus da ciência e da tecnologia, bem como da educação e do sistema de pós-graduação, estavam longe de ser favoráveis a grandes saltos e realizações, ao contrário do que uma leitura fria e descontextualizada dos documentos da época poderia induzir ou fazer acreditar.

Já o quarto plano, com um horizonte maior ( 1990-2002), que nunca existiu de direito, porque jamais foi promulgado, mas nem por isso foi menos real e deixou de existir de fato, tendo suas diretrizes adotadas pela CAPES, como lembra a Introdução, "[...] se caracterizou pelas ênfases na expansão do sistema, na diversificação do modelo de pós-graduação, na introdução de mudanças no processo de avaliação e na inserção internacional do SNPG [...]" "Trata-se da época dos governos das mais variadas colorações políticas - de Fernando Collor, passando por Itamar Franco, até os dois períodos de FHC. Resultado: se é que houve um plano nesse longo período, de fato não foi um único e o mesmo, mas mais de um ou ao menos um com uma multidão de retoques e adaptações $a d$ hoc, ao dar vazão à pressão dos contextos, e antes de tudo, às coerções econômicas e políticas.

Por fim, o quinto plano (2005-2010), tendo ao fundo os dois governos Lula, introduzirá novas e importantes inflexões, ao encontrar um sistema mais maduro e mais institucionalizado, sem as pressões do estado 
mínimo e do culto do mercado dos governos neoliberais. Conforme a Introdução, as suas principais características são:

[...] a introdução do princípio de indução estratégica nas atividades de pós-graduação em associação com as fundações estaduais e os fundos setoriais, o aprimoramento do processo de avaliação qualitativa da pós-graduação (conceito de nucleação, revisão do Qualis e implantação do PROEX), a preocupação com a solidariedade entre os cursos e seu impacto social, a expansão da cooperação internacional, o combate às assimetrias, a formação de recursos humanos para a inovação tecnológica no mundo globalizado e competitivo, e a ênfase na formação de docentes para todos os níveis de ensino, bem como de quadros técnicos via mestrado profissional para os setores público e privado ${ }^{6}$.

Sumariando os cinco planos, a Introdução de pronto reconhece seu protagonismo e assinala que eles foram responsáveis por

[...] cinco importantes etapas na história da pós-graduação brasileira: 1 - a capacitação dos docentes das universidades, formando o primeiro contingente de pesquisadores e especialistas em âmbito federal; 2 - a preocupação com o desempenho e a qualidade; 3 - a integração da pesquisa desenvolvida na universidade com o setor produtivo, visando o desenvolvimento nacional; 4 - a flexibilização do modelo de pós-graduação, o aperfeiçoamento do sistema de avaliação e a ênfase na internacionalização; 5 - a introdução do princípio de indução estratégica, o combate às assimetrias e o impacto das atividades de pós-graduação no setor produtivo e na sociedade, resultando na incorporação da inovação no SNPG e na inclusão de parâmetros sociais no processo de avaliação. Destaca-se assim - conclui a Introdução - um forte componente de continuidade na gestão e na condução das atividades da agência face à sua missão institucional, aí incluída a efetiva participação da comunidade acadêmica ${ }^{7}$.

É este o quadro em que se inscreve o sexto plano, o PNPG 20112020. O fundo são os planos anteriores, os legados históricos, o momento atual do país, os desafios que despontam e os grandes gargalos que nos ameaçam. Vivemos num país que cultua o jeitinho e descrê de planos e ações concertadas. Trata-se sem dúvida de um caldo de cultura que não favorece em nada ações como as ensejadas aqui, e de um país de mercadores e de predadores, não exatamente de inovadores e provedores, como os americanos e os europeus em tempos mais recentes, mas que também têm seus problemas. A isso se soma, independentemente das localidades e dos hemisférios, a própria natureza da ação humana - lugar de riscos e de 
imprevistos, que jamais poderão ser neutralizados e cancelados. Soma-se ainda, noutro nível das considerações e das desconfianças, o paradoxo das consequências, associado aos riscos e imprevistos, e também aos hiatos e gaps entre a intenção dos agentes, individuais e coletivos, e os resultados efetivos, podendo extrapolar as intenções e entrar em choque com elas. E somam-se, enfim, as chamadas profecias autorrealizadas, que não podem ser desmentidas, e que só dão certo se quem planeja a ação e intenciona o resultado é quem a executa e controla a execução. Por isso, de nada serviriam as ações de governos e os planos como os da CAPES, que dependem da sociedade e dos indivíduos, com a agravante de que, ao patrocinar seu sistema de avaliação, trouxe o maior dos males para as academias e as marcou com o selo da morte certa: o taylorismo acadêmico e o terror da transparência próprio das sociedades auditadas, que perderam a confiança nos indivíduos e procuram controlar tudo. Certamente tudo isso poderia ser arguido e levantado contra a CAPES e seus planos, dizendo que se alguma coisa deu certo não é por sua causa, mas malgrado eles, em razão da dinâmica do sistema e de um esforço coletivo que vão além dos governos e das agências. Com certeza, tudo isso poderia ser dito e questionado. Contudo, para lançar mão de uma metáfora religiosa, bem pesadas as coisas, só um desalmado não reconheceria que a CAPES e seus Planos, com todas suas distorções, abriram o caminho e protagonizaram uma mudança profunda no conjunto da educação brasileira, ao criar o SNPG. E o que é importante: ao protagonizar a mudança, ela o fez num curto espaço de quarenta anos e numa instituição como a universidade, que está habituada a medir suas ações e seus resultados com parâmetros mais dilatados, lastreados na cultura, nos laboratórios e no ethos, sugerindo que se está diante de alguma coisa nada comum na vida das instituições.

Os resultados dessa grande mudança podem ser apreciados nas Figuras 1 e 2, que descrevem o crescimento de cursos e discentes e o crescimento da produção científica e sua participação mundial (ver detalhes no cap. 3 do PNPG vol. 1 - Situação atual da pós-graduação).

De saída, na Figura 1, vemos que o número de cursos oferecidos evoluiu em uma curva ascendente, com as seguintes taxas de crescimento em perspectiva comparativa entre os anos de 1976 e 2009: houve um crescimento anual de 5\% no número dos cursos de mestrados, $14,7 \%$ no de mestrados profissionais e 6,6\% no de doutorado. De 2004 a 2009, 
Figura 1

Evolução do número de cursos

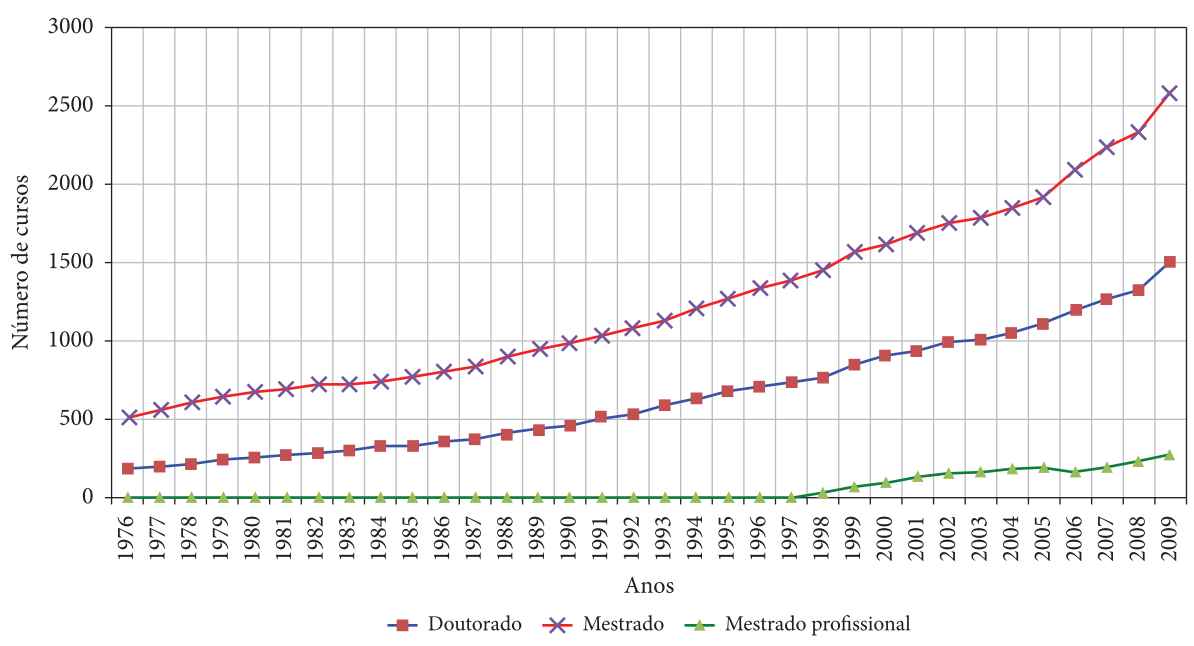

houve um crescimento anual de $6,9 \%$ no número de cursos de mestrado e de $7,6 \%$ no de doutorado, enquanto o crescimento do número de cursos de mestrado profissional foi de $7,8 \%$.

Por sua vez, o crescimento dos números absolutos de alunos matriculados, novos e titulados no nível de doutorado, no período de 1987 a 2009, é apresentado na Figura 2. O número de alunos matriculados cresceu de 8.366 para 57.923; o número de alunos novos evoluiu de 1.796 para 14.155; e o número de titulados de 864 alcançou 11.368. O crescimento percentual absoluto de alunos matriculados no período foi de mais de $600 \%$, o de alunos novos atingiu cerca de $700 \%$ e o de alunos titulados alcançou os $1300 \%$. Por fim, a taxa de alunos titulados por alunos matriculados evoluiu de aproximadamente 10\% em 1987 para 20\% em 2009.

Quanto ao mestrado, a evolução dos discentes no período de 1987 a 2009 evidencia um crescimento absoluto da ordem de 300\% para o número de matriculados; 485\% para novos alunos; $970 \%$ para os titulados.

Associado a essa expansão, houve um incremento da taxa de crescimento do número de titulados no mestrado e no doutorado por 100.000 habitantes: enquanto em 2006 o total de titulados mestres e doutores foi de 17,39 e 5,05, respectivamente, em 2009 os valores atingem 20,08 de mestres e 5,92 de doutores. 
Figura 2

Evolução do número de alunos de doutorado matriculados, novos e titulados - 1987 a 2009

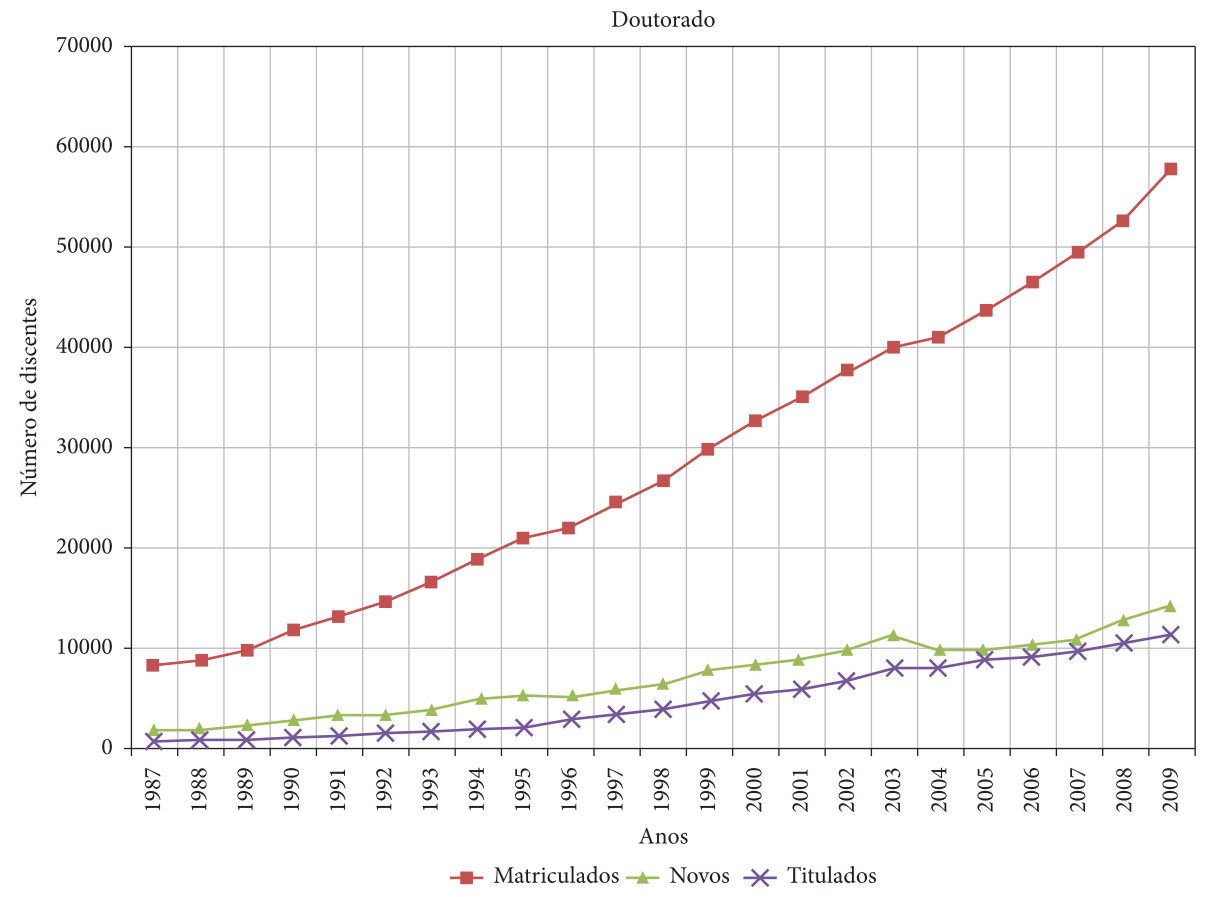

Esse desempenho da pós-graduação é acompanhado pela produção científica. A produção de artigos segue um crescimento superior ao aumento da população. Em 2000 foram publicados 6,14 artigos por 100.000 habitantes, enquanto em 2009 este número chegou a 17,93. As Figuras 3 e 4 mostram que o número de artigos publicados por brasileiros e sua participação na produção mundial cresceram de maneira significativa, levando a ganhos de posições nas estatísticas internacionais.

Em consequência de números tão favoráveis, o Brasil ultrapassou a Rússia e a Holanda em 2008 e passou a ocupar o $13^{\circ}$ lugar na base do ISI e $14^{\circ}$ lugar na base Scopus. Em 2009, ambas as bases indicavam o Brasil na $13^{a}$ posição em números de artigos publicados.

Finalmente, no que tange ao impacto relativo, em termos de médias de citações de artigos científicos para todas as áreas do conhecimento em 
Figura 3

Número de artigos publicados por cientistas ativos no Brasil

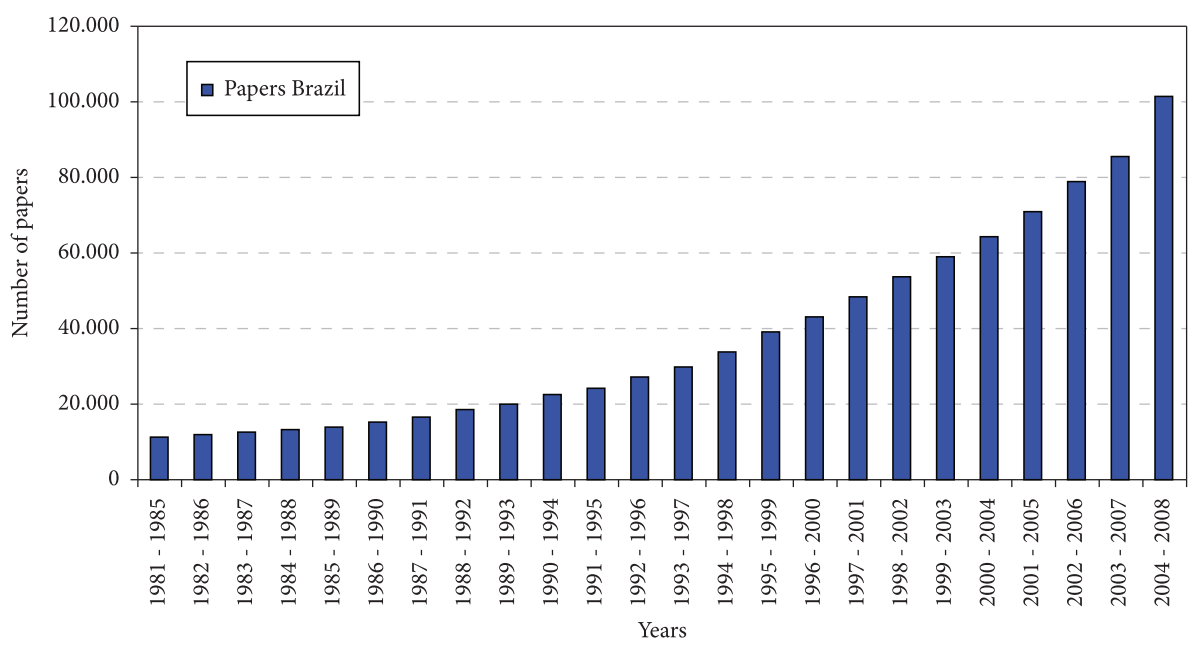

Figura 4

Participação das publicações brasileiras em relação ao total mundial

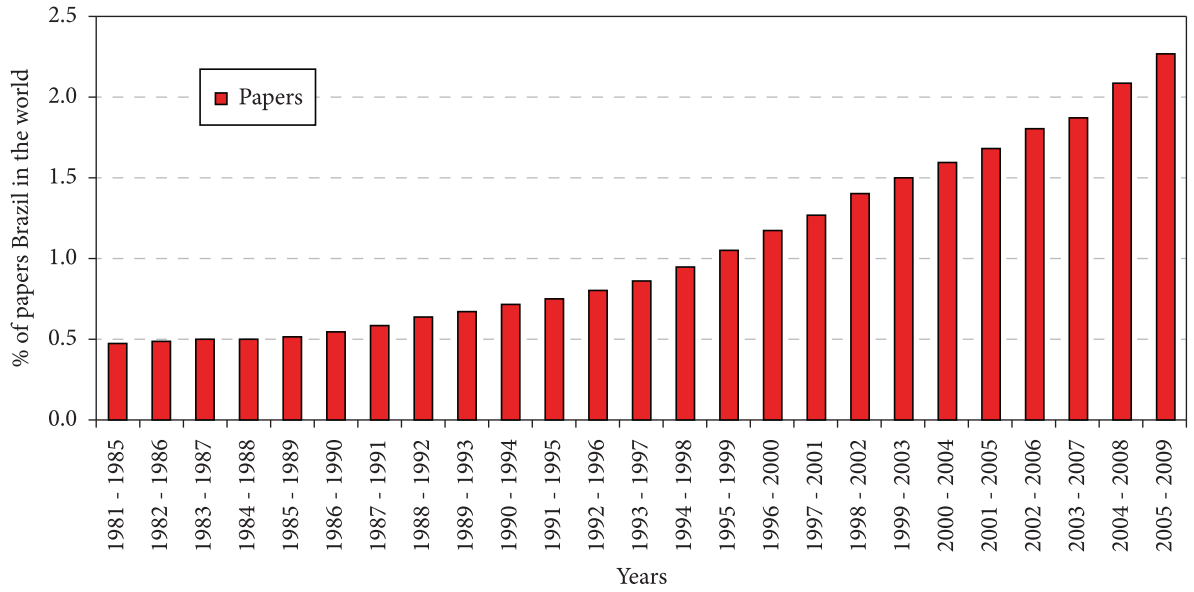

conjunto, o Brasil estava à frente dos demais países do BRIC (China, Índia e Rússia), como mostra a Figura 5. Mas as curvas indicam que a posição do Brasil está ameaçada pela China e pela Índia.

Segundo a Base Scopus, entre os anos de 1981 e 2008, a taxa de crescimento da produção brasileira de artigos científicos é maior do que a média mundial. Em 2007, o Brasil encontrava-se na $15^{\circ}$ posição entre os 
países cientificamente mais produtivos, e, em 2008, o país alcançou a $13^{\circ}$ posição, de acordo com a Web of Science.

Ao lado dessas realizações extraordinárias dos planos anteriores, há pesadas distorções e números preocupantes no cenário atual, quando focalizados outros aspectos da produção científica e tecnológica, como mostra o caso das patentes, e os quais serão abordados daqui a pouco.

Antes, porém, nas páginas que seguem, iremos focalizar o sexto plano e suas novidades. Muitas serão as continuidades em relação ao quinto plano, como o combate às assimetrias, a ênfase na inclusão social e a busca da internacionalização. Não faltarão inflexões importantes na avaliação e nas ações estratégicas, lastreadas pela proposta de criação de uma Agenda Nacional de Pesquisas, em parceria com o CNPq, a FINEP e as FAPs. No nível conceitual, a principal novidade foi a adoção de uma visão sistêmica nos diagnósticos, diretrizes e propostas, levando à busca da articulação e emaranhamento dos temas, em vez de sua separação e desmembramento. Outro conceito importante, associado à diretriz de combater as assimetrias

Figura 5

Impacto relativo das publicações dos países do grupo BRIC

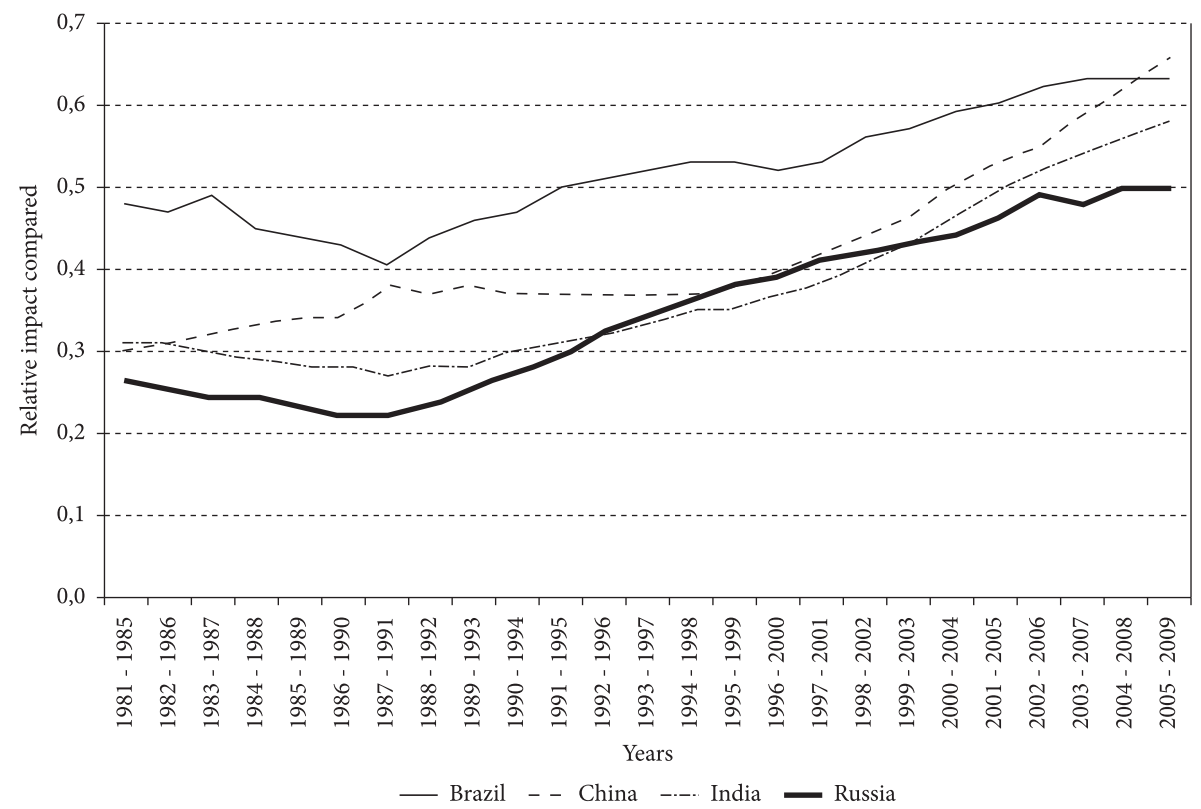


do SNPG, é o de mesorregião, que fornece a ferramenta para evidenciar as distorções no interior de uma mesma região. Somem-se ainda o modelo humboldtiano de universidade, fundado na associação do ensino e da pesquisa, como o da velha Universidade de Berlim, hoje Universidade Humboldt, e o modelo da tríplice hélice, proposto por Gibbons e Nowotny (GIBBONS et al., 1994) para operar a associação Universidade/Empresa/ Estado. Voltaremos aos dois modelos no fim do artigo.

O contexto mais amplo é o Brasil, seu imenso potencial, os desafios da atualidade, a situação do ensino e os gargalos do sistema. $\mathrm{O}$ maior dos desafios, ao formatar o Plano, será o de promover o ajuste do sistema de ensino de pós-graduação ao momento pelo qual passa o país, ao se transformar num dos BRICS. E de um modo especial, diferente dos outros integrantes do grupo, ao se ver reunir no firmamento do hemisfério sul uma constelação de fatores única em sua história, ao juntar - para o bem e para o mal - uma revolução urbana sem precedentes no Ocidente, uma revolução verde que transformou o país na terceira potência agrícola do planeta e uma taxa demográfica quase europeia, interrompendo o crescimento vertiginoso da população nos últimos 130 anos. O resultado é aquilo que os demógrafos e economistas vislumbram como uma rara janela de oportunidade - a janela, como salienta a Introdução, “[...] de vencer nossas heranças sociais-históricas, pagar a dívida social e criar uma sociedade de bem-estar"". Oportunidade que simplesmente será jogada fora se não forem vencidas as duas grandes barreiras sistêmicas que os governantes teimam em ignorar: o apagão do ensino médio, que deixa mais da metade da população fora do sistema; o gargalo do ensino superior, com 13\% dos jovens nas universidades, a maioria no sistema privado, sem tradição em pesquisa e incapaz de disseminar a cultura de CT\&I, essencial para o desenvolvimento com qualidade. Em contraste, a pequena fração que irá para as públicas - consideradas as melhores, mas não a totalidade, visto que, em grande parte, estão acomodadas e em patamar abaixo da missão que lhes é confiada - estará melhor aquinhoada em certas federais e estaduais, as quais também terão seus gaps e distorções, muitas vezes com práticas de ensino obsoletas e disseminando conhecimentos com décadas de atraso.

Estes pontos, que fornecem o contexto do PNPG 2011-2020, serão tratados no próximo item. 


\section{LEGADOS, DESAFIOS E PERSPECTIVAS}

Ao longo do volume 1, acompanhando as considerações, as diretrizes e as propostas do Plano, o leitor encontrará uma série de informações contextuais, ligadas à economia, à política de governos, à ciência e à tecnologia, ao sistema de educação, em escala nacional e mundial. Tratava-se de um esforço analítico necessário para fornecer aos governantes, membros do Congresso e formadores de opinião o quadro em que vai inscrever-se o sexto plano, quadro que de fato é mais de um, uma vez que, além do atual e real, foram adicionados os quadros virtuais e projetados para o futuro, havendo muitas vezes mais de uma alternativa ou de um caminho possível. Muitas das informações que estão dispersas no volume serão reunidas neste item, ao mesmo tempo que, paralelamente, outros elementos provenientes de diferentes estudos e dos mais diversos experts serão acrescentados, tendo como mote os legados, os desafios e as perspectivas tanto do mundo globalizado em que vivemos, quanto do sistema da pós-graduação brasileira.

Ora, como é sabido, o contexto mundial é de grande perturbação e incerteza, desafiado pela crise financeira que vem causando estragos terríveis na Europa, na América do Norte e no Japão. E desafiado ainda, no plano político e nas outras pontas da atividade econômica, abarcando a indústria e a agricultura, pela necessidade de integrar uma massa enorme de indivíduos, fornecendo-lhe aqueles bens, comodidades e serviços da chamada "sociedade de bem-estar" - sociedade que, se é verdade que está com seus fundamentos abalados nos países centrais, nem por isso perdeu seu poder atrativo junto às populações dos quatro cantos do planeta. Deixando de lado a crise financeira, o atendimento a essas expectativas de uma Welfare society estendida exigirá um esforço colossal, devido à magnitude da escala e à pressão ambientalista pró-disseminação de tecnologias limpas tanto na agricultura quanto na indústria.

Ao focalizar esse ponto perturbador, a Introdução do vol. 1 formula com precisão os termos do problema e a sua magnitude, bem como assinala o papel do Brasil nesse cenário e a repercussão sobre a pós-graduação, levando em consideração a agricultura:

A escala do desafio não poderia ser maior: como alimentar nos anos que virão, sem degradar o ambiente, mais de oito bilhões de indivíduos constituindo uma massa enorme de população urbana, com uma renda cada vez mais elevada 
e um padrão de consumo mais e mais exigente? Haverá a necessidade de produzir mais grãos, além de responder à demanda por mais proteínas, diante da projeção de crescimento do consumo mundial da ordem de $100 \%$ até 2020 . O Brasil poderá ser o principal ator neste cenário. Os diferentes Programas de Pós-Graduação em ciências agrárias deverão ajudar a encontrar uma resposta para esta questão pungente ${ }^{9}$.

Obviamente, a escala e a magnitude dos desafios não serão menores ao se passar da agricultura para a indústria e do campo para as cidades, com os indivíduos vivendo mais e mais, entregues a um consumismo sem peias, solitários pontos na imensa rede da Web e estressados nas megalópoles espalhadas pelo mundo afora. Será então a vez das engenharias, da informática, da saúde e das ciências sociais aplicadas de serem convocadas e darem a sua contribuição.

Voltando ao contexto econômico mundial e ao Brasil, o Plano reconhece que o país transformou-se profundamente nos últimos dez anos: 80\% da população está nas cidades; a EMBRAPA patrocinou uma verdadeira revolução no campo, ao incorporar o cerrado e disponibilizar o emprego de tecnologias adequadas, promovendo em vinte anos (1990-2010) o salto da produção agrícola em mais de $140 \%$ e o acréscimo da área cultivada em apenas $25,9 \%$, e transformando o país no terceiro exportador mundial; o nível da renda média do brasileiro aumentou, turbinado pelas políticas de inclusão e a expansão da classe $\mathrm{C}$; a isso se somam feitos extraordinários em segmentos importantes da tecnologia espacial, petrolífera e agroindustrial, exemplificados pela EMBRAER, que se transformou no terceiro fabricante de aviões, pela Petrobrás, líder mundial na prospecção de petróleo em águas profundas, e pelo etanol de cana de açúcar, considerado pouco poluente e de grande eficiência. O resultado dessas transformações ainda está sendo processado, e deverá ser aprofundado e adensado nos anos que virão. De um lado, somos hoje a sétima potência econômica mundial e em breve seremos a quinta. De outro, a percepção externa de nosso país mudou, fomos integrados ao grupo dos chamados BRICS e convocados para desempenhar um novo papel no concerto internacional das nações, ao mesmo tempo que internamente melhorou a nossa autoestima. Com alguma facilidade, trocamos a pecha do complexo de "vira-lata" cunhado por Nelson Rodrigues por certo encantamento narcísico por nós mesmos. Todavia, tudo é recente demais e continua nos faltando certo refinamento nas 
maneiras e nos costumes, podendo justificar em nível mundial a percepção dos turistas brasileiros como Latin american trash.

Quanto aos feitos extraordinários e à perspectiva de o país se transformar na quinta potência econômica mundial, com um mercado interno respeitável, justificando as celebrações e mais ainda dos governantes, que acreditam que são deuses e que foram eles que fizeram tudo, os autores entendem que há grande exagero em muito do que é dito e não compartilham do ufanismo tolo que cerca ambientes poderosos de Brasília e de outros centros. Tal é o caso da classe $\mathrm{C}$, injustificadamente chamada de classe média ao incorporar aquelas famílias que ganham dois salários mínimos e meio, e celebrada pelos círculos oficiais: certamente, este segmento da população está ajudando a expandir a economia e descobrindo o paraíso do consumo ao adquirir TVs de última geração, viajar de avião e comprar carros de segunda mão, mas não poderão enviar os filhos para as universidades e proporcionar o aumento da matrícula no ensino superior, que já bateu no teto. Por outro lado, os autores entendem e isso pode ser averiguado em diferentes trechos e nas entrelinhas dos diversos capítulos que constituem o primeiro volume, que o PIB brasileiro cresceu muito, como acabamos de assinalar, e que o país suportou bem a crise financeira de 2008, crise que - diga-se de passagem - ainda não acabou e está devastando a Europa e a América do Norte. Todavia, não nos iludamos. A ciência econômica muitas vezes é por demais hermética, aliando a grande tecnicidade do formalismo matemático à desfaçatez de opiniões interessadas dos consultores e operadores de bolsa. Por seu turno, a economia real dos países segue vias tortas, algo randômica e enviesada, desmentindo as previsões e defenestrando as modelagens. Simplesmente, não há relação necessária e direta entre crescimento externo e crescimento interno, nem relação inversa ou indireta, como muitos gostariam. Contrariamente ao que se diz, não foi a primeira vez em nossa história recente que tiramos partido de conjuntura externa adversa e crescemos: assim, depois do crash de 29, houve uma grande crise mundial, acompanhada de estagnação e mesmo queda da economia dos países centrais, resultando na Grande Depressão, enquanto a nossa cresceu muito, lastreada pela substituição das importações e abrindo o caminho para a industrialização, diferentemente da Argentina, que seguiu outras rotas. Nos anos 80-90, conhecidos como a década perdida, houve a grande estagnação da nossa economia e nos demos mal, enquanto a economia mundial estava 
bem. Nos últimos dez anos, soubemos nos aproveitar do boom mundial e da fome chinesa por commodities. Agora, a economia mundial entrou em crise, ao passo que a dos BRICS, e junto com ela a do Brasil, não, tendo sido, até o presente momento, bastante poupada. Até quando, não sabemos.

A favor de nós conta a janela de oportunidade da demografia, antes comentada, e também a constelação única da economia propiciada pela revolução agrícola, pelo agronegócio e por segmentos da indústria assim como dos serviços. Contra nós há problemas sistêmicos sérios de várias ordens: infraestrutura, logística, competitividade, accountability (responsabilidade associada a prestação de contas), cultura, etc. Nossa posição entre os BRICS não é confortável. Ganhamos da África do Sul e da Rússia em vários domínios, mas estamos sendo batidos pela China e a Índia em inúmeros fundamentos econômicos. Nos últimos dez anos, segundo o FMI, entre 2000 e 2010 a participação da economia brasileira no PIB mundial, medida em termos de PPP (Purchasing Power Parity $=$ Paridade de Poder de Compra) ficou estacionada na faixa dos 2,9\%, tendo inclusive observado uma pequena queda de $0,2 \%$, ao passo que o peso relativo da Índia, menor do que a brasileira em termos de US\$ nominal, aumentou de $4 \%$ para 5\% e a China teve um salto estratosférico de 7\% para 13\%. Por sua vez, em outra comparação importante, o ranking de competitividade do IMD [International Institute for Management Development] sediado na Suíça, no último levantamento realizado em 2011 para um conjunto de 59 países, mostra Hong-Kong e USA no topo, ao mesmo tempo que evidencia que o Brasil perdeu nos últimos anos 6 posições, ao cair de 38 para $44^{\circ}$ lugar, enquanto o México pulou de 47 para $38^{\circ}$. Pior: se for computada a eficiência do poder público, em contraste com a empresarial, que não é lá essas coisas, o Brasil ficará com o 55\% lugar. Já no ranking inovação levantado pela The Global Innovation Index/Insead, com sede nos USA, coloca a Suíça no topo, Os Estados Unidos em $7^{\circ}$, a China sem Hong-Kong em $29^{\circ}$ e o Brasil em $47^{\circ}$ lugar. Não bastasse, há ainda as patentes, domínio em que o desempenho do Brasil é lamentável, aparecendo no ranking de 2010 da OMPI (Organização Mundial da Propriedade Intelectual = WIPO em inglês) na $24^{a}$ posição, com 492 depósitos, enquanto os Estados Unidos aparecem na $1^{\mathrm{a}}$ (44.890), seguidos do Japão na $2^{\mathrm{a}}$ (32.180), da Alemanha na $3^{\mathrm{a}}$ (17.558), China na $4^{\mathrm{a}}(12.295)$, da Coreia do Sul na $5^{\mathrm{a}}(9.668)$ e da Índia na $17^{\mathrm{a}}$ posição (1313). (Cf. vol. 1, p. 189, que se refere ao ranking de 2009 , 
em que o Brasil aparece em $25^{\circ}$ lugar e a China é batida pela Coreia do Sul, situações que serão alteradas em 2010, quando a China ultrapassa a Coreia do Sul). Para o leitor fazer uma ideia da situação vexaminosa para nós que nos julgamos tão criativos e espertos, outro levantamento importante, da USPTO (United States Patent and Trademark Office), desta vez considerando as patentes concedidas, nos mostra perdendo feio para um monte de países, até mesmo para a Malásia. Na sequência do artigo, voltaremos às patentes, quando iremos mostrar outros quadros comparativos, com um escopo mais abrangente. Por ora, cabe salientar que na série histórica, tomando como referência os últimos quarenta anos, o Brasil vem perdendo posições para emergentes asiáticos: Taiwan (1975), Coreia do Sul (1983), China (1986), Cingapura (1996), Índia (1998) e Malásia (2007).

Não vamos mais nos alongar sobre estes importantes tópicos. Para sumariar tudo, compreender o contexto mundial em que se inscreve o sexto Plano, e sopesar os desafios que a economia e a sociedade brasileira estão a colocar para o sistema de ensino, inclusive a pós-graduação, é preciso considerar que a economia mundial mudou e muito, tendo passado por um processo de desmaterialização profunda, com a geração da riqueza não mais dependente exclusivamente da produção de bens físicos, industriais ou agrícolas. O resultado é aquilo que os economistas costumam chamar de financeirização e mesmo de informacionalização. Atentos a isso e a outros aspectos que vão além da economia, um grupo de estudiosos cunhou e pôs em circulação a expressão de "Sociedade da informação", rebatizada por outros de "Sociedade do conhecimento", ao evidenciar o quanto o capitalismo hoje depende mais e mais da aplicação do conhecimento e do uso de tecnologias intensivas.

Um excelente exemplo dessas mudanças em curso é a indústria de aviões, como mostra o caso da Boeing nos projetos do B 17, na década de 1940, e do Boeing 777, cinquenta depois. No cap. 9, o PNPG 2011-2020 mostra a mudança formidável pela qual passou o processo de fabricação da aeronave famosa, colocando em evidência o número de engenheiros nas equipes e a mudança da natureza da atividade técnica, com profunda repercussão sobre a economia. Ou seja:

Enquanto que no primeiro [B 17] havia menos de 100 engenheiros no projeto, o segundo envolveu 5.600 desses profissionais (The New York Times, 10 de novembro de 1991). Isto se deve ao processo de aumento de quantidade de trabalho sobre 
a informação em relação à quantidade de trabalho sobre a matéria, isto é, a 'informacionalização’ da economia. Mesmo sem dispor de outros exemplos quantitativos, é lícito considerar que, a exemplo do que aconteceu na Boeing, os custos na indústria vêm se deslocando rapidamente para as atividades de concepção e projeto dos produtos e processos ${ }^{10}$.

Entendemos que esse exemplo emblemático mostra com precisão as duas grandes mudanças que irão alterar profundamente não só o perfil do engenheiro, mas também da própria economia, levando a profundas inflexões nas relações entre os países centrais e os periféricos. Mudança do perfil do engenheiro: ele deixará de ser o fazedor e calculador, pois outros técnicos vão fazer e operar em seu lugar, e em vez de ele mesmo calcular, como diz o Prof. Paulo Blikstein, de Stanford, “[...] são as máquinas e os computadores que farão a matemática da engenharia, deixando para o profissional o trabalho criativo [...]". Então, na acepção própria do termo, o engenheiro engenha e se verá na companhia do artista, como aliás reconhece Blikstein, ao dizer que "A engenharia está cada vez mais próxima do design e mais longe do modelo calculista [...]"11. Mudança de perfil da economia: por um lado, a escala deixará de ser o país ou a nação e passará a ser o mundo, resultando na crescente globalização e no compartilhamento das atividades em P, D\&I por escritórios e laboratórios em diferentes localidades do globo; por outro, haverá a desindustrialização dos países centrais, por toda sorte de motivos, inclusive custos de mão de obra, e a transferência do parque industrial para a periferia do sistema. Será então a vez da Ásia, com a Coreia do Sul se enriquecendo em poucas décadas e a China apresentando hoje um contingente de engenheiros maior do que o existente nos USA. Em contraste, favorecido pelo mesmo processo, o Brasil cresceu, mas não com o mesmo ímpeto e a mesma velocidade dos asiáticos. A exceção foi a agricultura, a pecuária e o agronegócio, embalado pela Embrapa.

Resultado: o Brasil será a $5^{a}$ potência (PIB US\$), a concorrência ficará mais e mais acirrada, e o laço entre economia e CT\&I ficará cada vez mais estreito. Tendo chegado aonde chegamos, poderemos sonhar mais longe e - com a ajuda da ciência e da tecnologia de que já dispomos, fomentada e difundida pelas universidades e institutos de pesquisa, bem como da parcela de que em breve esperamos dispor pelas ou nas empresas - nos propor a implantar a sociedade de bem-estar entre nós, conforme aliás vaticinou o Plano. Precisamente, ao ensejar uma sociedade e uma economia fundadas 
não na depredação, como vínhamos fazendo, mas na sustentabilidade e seus três pilares: viabilidade econômica [crescimento com qualidade], justiça social e conservação ambiental ${ }^{12}$. Nada disso poderá ser feito sem ciência e tecnologia, disso quase ninguém duvida. E também do fato de que, para serem viabilizadas, a sociedade e a economia sustentáveis exigirão recalibrar as políticas públicas e pôr fim à formidável máquina de destruição criativa que, segundo Schumpeter, caracteriza o capitalismo e conduziu ao império das tecnociências. Império que foi implantado há cerca de 150 anos no Ocidente e que os USA, com seu dinamismo e empreendedorismo extraordinários, souberam levar ao estado da arte, mas que agora foi abalado em seu centro nervoso - Wall Street, os bancos e as finanças -, exigindo que alguma coisa seja feita: uma economia menos excludente e um mundo mais justo, e também uma relação com a natureza fundada na sustentabilidade e no uso de tecnologias limpas.

Este é, pois, o contexto do sexto Plano, com os desafios, os legados e as perspectivas. A perspectiva do Brasil não poderia ser melhor: está mais rico hoje, poderá investir mais em ciência e tecnologia, e será a quinta potência econômica no próximo decênio e a quarta em 2050. Tudo isso é muito bom e só um insano poderia duvidar de que o potencial do país é grande, devido aos imensos recursos naturais, contando a nosso favor a janela demográfica entreaberta e a constelação auspiciosa da economia. O Plano reconheceu e reconhece isso, deixando uma mensagem otimista. Todavia, não podemos ser ingênuos. Além do êxito e do sucesso, o fracasso e a meia-vitória estão inscritos no horizonte da ação e dos planos, e todo cuidado será pouco. Assim, junto com a esperança e o otimismo, não escondemos o nosso temor e as nossas reservas, visto que somos os primeiros a reconhecer que o país está mal preparado, poderá fechar a janela da oportunidade e mais uma vez perder o bonde da história. Isto, não por causa dos planos ou por falta deles, pois não são eles que estão em jogo, mas por causa de incúria política dos governantes e de nossos legados históricos, que são pesados e incontornáveis, podendo trancar a perspectiva que se entreabria e estragar tudo.

Se nos faz sorrir e faz bem para a nossa autoestima a ideia de que Deus nos abençoou e a natureza nos brindou com recursos naturais invejáveis, até mesmo o petróleo encontrado nas águas profundas de nossas costas marítimas, em contrapartida sabemos que somos pouco operosos 
e um passado colonial e mesmo pós-colonial por demais cruel deixou o nosso povo ao léu e despreparado. O resultado é conhecido e avassalador: os déficits em recursos humanos, os gargalos imensos no sistema de ensino e os gaps culturais profundos do brasileiro médio, tanto das elites quanto do povo, agravados pela corrupção endêmica, nunca punida no meio político, solapando a confiança nas instituições e condenando o futuro da nação.

Assim, no cap. 9 - Recursos Humanos para empresas: o papel da pós-graduação, o Plano considera que, com respeito

ao padrão de recursos humanos de nível superior, o Brasil apresenta um cenário preocupante, pois de acordo com o IBGE (2009 - síntese dos indicadores sociais) somente em torno de $13 \%$ dos jovens entre 18 e 24 anos estão matriculados em instituições de educação superior no Brasil. Na Argentina, o percentual correspondente é de 30\%, no Chile de 52\% e nos Estados Unidos de 60\%. Além disso, cerca de $70 \%$ do total das matrículas na educação superior no Brasil estão nas áreas de ciências humanas e sociais, enquanto apenas 11\% correspondem às engenharias e ciências tecnológicas (o percentual médio nos países da OCDE é de 30\%). Ou seja, isso significa apenas 1,5\% dos jovens brasileiros entre 18 e 24 anos estão matriculados em cursos de engenharias e ciências tecnológicas ${ }^{13}$.

Estamos, pois, diante de um verdadeiro gargalo, que se estende a todos os níveis de ensino, mesmo àqueles mais universalizados, como o ensino fundamental. $\mathrm{O}$ ensino médio, mais do que passagem obrigatória para o ensino superior, deveria oferecer opções consistentes para aqueles que não o podem ou não o querem, como cursos técnicos ou ensino profissional, além de levar adiante, como fim em si mesmo, a vocação de preparar o jovem para o exercício da cidadania. Contudo, não é bem isso o que vamos encontrar nesse nível do ensino brasileiro, que está a anos luz do Liceu francês, e apresenta números catastróficos, conforme mostra a sequência do trecho que estamos citando: simplesmente, “[...] menos de 50\% dos jovens entre 15 e 17 anos estão matriculados no ensino médio, onde a baixa qualidade do ensino tem sido comprovada pelo Sistema de Avaliação Básica (SAEB)"14. Ao se passar para o ensino fundamental, a situação piora ainda mais e se revelará "calamitosa" segundo o PNPG:

[...] dados do SAEB/INEP 2007 revelam que o percentual de alunos com desempenho acima do nível adequado em Língua Portuguesa e Matemática, na $4^{a}$ série do ensino fundamental, foi respectivamente de $27,8 \%$ e $20,5 \%$ e na 
$8^{a}$ série do ensino fundamental, nas mesmas disciplinas, foi respectivamente de $23,7 \%$ e $14,3 \%$, ou seja, muito aquém das habilidades e competências mínimas para resultar em uma futura formação científica ${ }^{15}$.

Os mesmos números ruins serão encontrados em outros rankings, como no exame de Pisa, organizado pela OCDE, abarcando os dois níveis de ensino e focalizando o desempenho em leitura, matemática e ciência: no último levantamento, realizado em 2009, num universo de 65 países, o Brasil aparece na $53^{a}$ posição, e mostra que em leitura, p. ex., quase dois terços dos jovens têm desempenho baixíssimo. Tal situação, além da imagem do gargalo, sugere a existência de um verdadeiro apagão no nosso sistema de ensino médio e fundamental. Diferente e bem mais sério do que o apagão elétrico, ele não dura horas ou um dia, mas está durando séculos, vitimando os governantes que não enxergam o que se passa e não sabem aquilatar a extensão do estrago, e também os jovens e a população, condenados a viver nas trevas da ignorância e da mediocridade. Para se ter uma ideia tanto do apagão quanto do gargalo, o leitor poderá examinar a Figura 6, que estampa com clareza a nossa triste situação.

A figura em apreço apresenta os dados do PNAD para o ano de $2005^{16}$, referentes às atividades de estudo e trabalho dos jovens e crianças brasileiras. Os dados são distribuídos por idade, a partir de 5 anos até 25 anos. Os possíveis candidatos ao ensino de pós-graduação aparecem nas últimas faixas. Como se vê, a média na faixa de 20-24 anos estava em torno de $8 \%$ dos que apenas estudam. Incluindo aqueles que estudam e buscam trabalho ou estudam e trabalham, o número passa para 15-16\%. Pode-se dizer que, apesar do crescimento verificado no período 2005-2008, a oferta de candidatos à pós-graduação não é alta, estando abaixo de países como Chile e Argentina.

Tal situação compromete o desempenho almejado para o SNPG, e o sexto Plano levou essa barreira em consideração, não deixando de alertar as autoridades. Simplesmente, sem estudante e o aumento de seu efetivo, não existe pós-graduação nem expansão possível. A solução para esse grave problema exigirá tempo. Uma ação imediata seria induzir políticas educacionais, acompanhadas de recursos financeiros, que atinja a faixa de idade de 15 a 17 anos. Qualquer mudança na inflexão da curva mostrada na figura, nessa faixa de idade, terá um efeito positivo, após 8-9 anos, no número de possíveis candidatos à Pós-Graduação na idade de 25 anos. 


\section{Figura 6}

\section{Estudo e trabalho: jovens e crianças brasileiras}

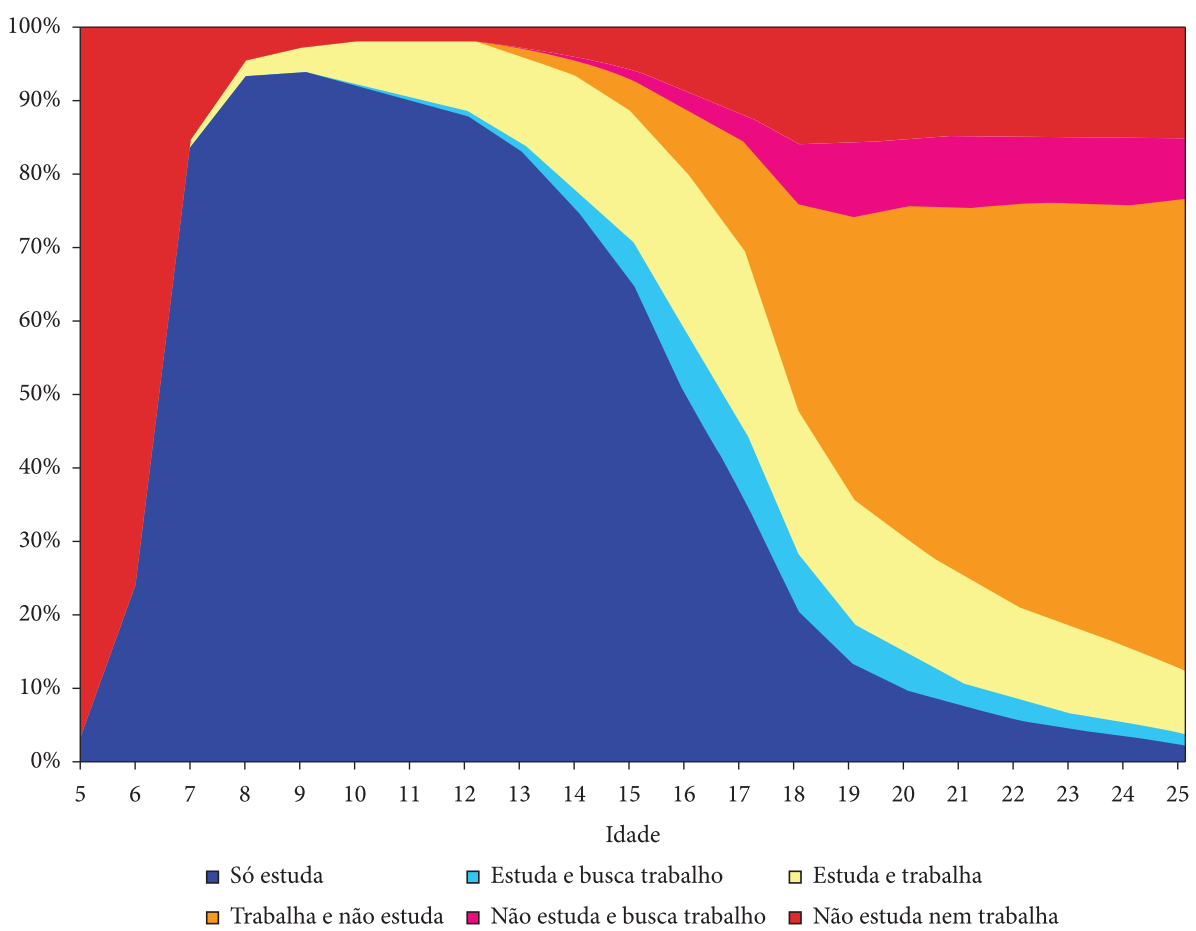

O resultado é conhecido: um caldo de cultura ruim, uma mão de obra despreparada e os gaps de todo tipo que serão encontrados em todos os segmentos da sociedade brasileira, repercutindo no ensino superior e na pós-graduação. Como se sabe, nossas universidades são cartoriais, bacharelescas, investem pouco em pesquisa, priorizam o diploma sobre a competência, dão pouco valor à criatividade e não difundem a cultura de inovação tecnológica - donde a dificuldade enorme de incluir o I no modelo da CT\&I, e mesmo de pôr o C e o T na maioria delas. À diferença de outros países, que em certos planos do ensino superior, como naqueles mais ligados às engenharias, estão implantando o modelo da tríplice hélice (associação Universidade, Empresa e Estado), no Brasil estamos longe disso, e não só porque faltam às nossas universidades os meios e a cultura, mas pelo déficit da cultura da inovação na maior parte do empresariado brasileiro, como assinala o Plano ${ }^{17}$. 
Concluindo esse tópico, podemos aquilatar o peso dos legados, a altura das barreiras e a extensão dos desafios. Tendo compreendido a escala das coisas, pode-se partir para a formatação do plano de ação, definindo as prioridades e estabelecendo a agenda. Foi o que realizamos no âmbito das comissões, cujos resultados, com os riscos que os acompanham, inclusive o de errar feio, estão materializados em diferentes trechos e capítulos do volume 1.

Assim, os desafios e as prioridades, elencados no fim do cap. 9 sob a ótica do mundo empresarial, com destaque para a adoção de cursos técnicos superiores de curta duração; a ampliação do parque da pós-graduação brasileira com foco nas engenharias, em segmentos da saúde e no agronegócio; a ênfase na captura e formação de talentos para apoiar os processos de inovação do parque industrial do país; a implantação de redes de produção do conhecimento, visando a melhor integração entre universidades, governo e empresas, e baseadas na interdisciplinaridade, na aplicabilidade e na responsabilidade social, mediante a adoção de políticas públicas e protocolos de conduta preocupados com a sustentabilidade ${ }^{18}$. No fim do cap. 10 - Recursos humanos e programas nacionais, com uma abrangência maior, aparecem outras prioridades, com incidência sobre o marco regulatório, considerado ultrapassado e excessivamente burocratizado, onerando as empresas e obstaculizando a pesquisa: trata-se do tão falado "custo Brasil", que deverá ser pesadamente desonerado para aliviar as empresas e as instituições acadêmicas, bem como ter os procedimentos e os processos revistos e simplificados ${ }^{19}$.

Quanto à Agenda, trata-se da agenda da pesquisa, tomando como modelo a experiência da Austrália, abarcando a ação de vários ministérios e tendo as instituições de ensino superior como parceiras, incluídos os programas de pós-graduação. Trata-se, no caso da Austrália, do modelo da tríplice hélice, envolvendo ações e parcerias entre órgãos públicos e privados nos setores de meio ambiente, agroindústria e tecnologia de informação e comunicação. O Plano pretende que um modelo semelhante pode ser adotado no Brasil, devendo buscar a sinergia entre as propostas do PNPG 2011-2020 e a IV CNCTI (Conferência Nacional de Ciência, Tecnologia e Informação), a qual, em 2010, lançou o Livro Azul em que aparece um conjunto de áreas prioritárias e que em alguma extensão já estão presentes no SNPG, cabendo dar-lhes um apoio mais decidido. Evidentemente, ao criar a 
Agenda Nacional da Pesquisa, além dos elementos fortemente pragmáticos das ciências aplicadas e das engenharias, deverão ser contemplados os elementos teóricos e especulativos das ciências básicas e de outras áreas do conhecimento, proporcionando a retroalimentação do sistema. Voltaremos a esses pontos na sequencia do artigo.

É neste quadro que se inscreve o pré-sal, de início fruto dos acasos de prospecções randômicas, e destinado agora a entrar na Agenda Nacional da Pesquisa, com grande impacto no futuro de nossa economia, e exigindo um esforço nacional de monta para a formação de grande contingente de recursos humanos para a Petrobrás e empresas correlatas. De modo similar, outros temas ou matérias que irão integrar a Agenda, considerados estratégicos para uma região ou para o conjunto da nação. Em todos eles, conforme vimos, o esforço suplementar por um plus na formação de quadros, justificando as campanhas, a mobilização do país e a destinação de fábulas de recursos, irá esbarrar no mesmo obstáculo, conforme assinalamos: o fato de o sistema educacional brasileiro perder uma grande quantidade de alunos ao longo do tempo, sendo insignificante o número dos matriculados nas séries iniciais do ensino fundamental que concluem a educação superior. Daí o Plano alertar no cap. 8 - Educação básica - um novo desafio para o SNPG: “[...] a pretensão de ampliar o número de alunos em alguns de nossos cursos de mestrado e doutorado acaba prejudicada pela falta de alunos capacitados e com disponibilidade para tal [...]" e "[...] se quisermos ampliar o número de alunos nos cursos de mestrado e doutorado, temos que melhorar a eficiência do sistema como um todo, sobretudo a etapa educação básica." ${ }^{20}$. Embora não seja da alçada da CAPES e não possa integrar as metas do PNPG, esta é a prioridade zero ou a prioridade das prioridades.

\section{EIXOS, ÊNFASES E RECOMENDAC̣̃̃ES}

Não é nossa intenção replicar o vol. 1 ou resumir os principais tópicos - tarefa não só impossível, mas inútil. Como nos itens anteriores, aqui iremos ater-nos ao nosso propósito de explicitar aspectos do Plano que ficaram implícitos, bem como de externar nosso ponto de vista, com a vantagem e o ônus, conforme assinalamos, de estarmos agora desobrigados 
do Colegiado e dos Comitês - o que certamente cria uma situação nova. Quem quiser os detalhes e os complementos de nossas considerações, deverá consultar o livro, que está disponível e deve ser considerado como referência intransferível e insubstituível. A exemplo dos tópicos anteriores, faremos algumas breves citações do Plano, para introduzir ou apoiar o argumento e para poupar o leitor da necessidade de consultar o tempo todo o texto.

Três são os assuntos que iremos comentar: os eixos, as ênfases e as recomendações.

Comecemos pelos eixos: eles são cinco, e para sua caracterização iremos transcrever o trecho em que eles aparecem pela primeira vez, segundo parágrafo da Introdução:

1 - a expansão do SNPG, a primazia da qualidade, a quebra da endogenia e a atenção à redução das simetrias; 2 - a criação de uma nova agenda nacional da pesquisa e sua associação com a pós-graduação; 3 - o aperfeiçoamento da avaliação e sua expansão para outros segmentos do sistema de CT\&I; 4 - a multi, a interdisciplinaridade entre as principais características da pós-graduação e importantes temas de pesquisa; 5 - o apoio à educação básica e a outros níveis e modalidades de ensino, especialmente o ensino médio ${ }^{21}$.

Como foi comentado, em razão dos gargalos e do apagão que atingiram o ensino básico e fundamental, o sistema de pós-graduação está longe de ter batido no teto e deverá ser expandido para atender às necessidades do país. Além de ser extremamente baixa a presença de doutores nas empresas brasileiras, cuja maioria não tem departamento de $\mathrm{P} \& \mathrm{D}$, o sistema de ensino superior deverá ser expandido à medida que for sendo expandido o ensino médio, e, por conseguinte, for aumentando a demanda por mestres e doutores. Chegamos muito tarde à implantação das universidades entre nós, e mais tarde ainda à implantação da pós-graduação. Por isso, nada mais natural, pelos mais diferentes motivos, que os nossos números sejam extremamente acanhados se comparados com outros países. Tal é o caso do número de doutores: "EUA [com] 8,4 de portadores do título de doutorado por mil habitantes na faixa etária de 25 a 64 anos; Alemanha 15,4; Austrália 5,9; e o Brasil 1,4"22. Daí o Plano ter recomendado a expansão contínua do sistema, por entender que não está saturado, longe disso; não obstante, considera que há distorções, algumas áreas das humanidades estão infladas, e que outras das engenharias e afins estão subdimensionadas e deverão ser expandidas. Além das distorções intra-acadêmicas e internas ao SNPG, há as distorções 
regionais, com grande concentração de programas de pós-graduação no Sudeste, e escassa oferta no Norte e no Centro-Oeste - daí as recomendações para a criação de programas específicos para elas, aproveitando o potencial e a vocação das regiões, e também de combate das assimetrias das intrarregiões, mediante a ferramenta geoestatística das mesorregiões. Por fim, há que se considerar as distorções provocadas pela endogenia e o engolfamento do sistema, em razão do insulamento do país e do ensimesmamento da pós-graduação - distorção preocupante que deverá ser combatida com o estímulo à internacionalização, mediante o movimento de mão dupla de envio de estudantes - dos melhores, em suma - para fazer doutorado pleno no exterior e capturar o conhecimento no estado da arte, e da atração de profissionais e até mesmo estudantes estrangeiros, com o mesmo propósito e para oxigenar o sistema.

Quanto à criação de uma nova Agenda Nacional da Pesquisa, comentamos que, de acordo com o Plano, um bom modelo poderia ser os CRCs (Centros Regionais de Competência) da Austrália ${ }^{23}$ e acrescentamos que uma boa plataforma poderia ser o programa da IV CNCTI, que escolheu como áreas prioritárias cerca de 10 campos da atuação, com forte viés tecnológico: "biotecnologia, fármacos, medicamentos e vacinas, materiais avançados, nanotecnologia, tecnologia da informação e da comunicação, microeletrônica, espaço, defesa e energia nuclear" ${ }^{24}$. O cap. 9 - Recursos humanos para empresas: o papel da pós-graduação, inclui na Agenda, além da indústria farmacêutica, energia (in extenso, não tão só nuclear) e tecnologias da informação e da comunicação, áreas como agronegócios, alimentos, eletrodomésticos, siderurgia, aeronáutica, automotiva, petroquímica, química e médico-hospitalar. Por sua vez, o cap. 10 - Recursos humanos e programas nacionais, aumenta a lista mais ainda, depois de reconhecer a importância estratégica da Amazônia, da Amazônia Azul (costa marítima), do Cerrado, da Energia (inúmeras), do Controle de Fronteiras, do Programa Espacial, da Segurança Pública, entre outros. Conforme ressaltado supra, ao propor a criação da Agenda Nacional da Pesquisa, os responsáveis pelo Plano sabem que, além desses elementos fortemente pragmáticos das ciências aplicadas e das engenharias, deverão ser contemplados os elementos teóricos e especulativos das ciências básicas e de outras áreas do conhecimento, permitindo a calibragem dos dois grupos. Este é o caso da astrofísica, das matemáticas dos fractais e das topologias, da teoria da evolução, das 
neurociências, etc., que estão na fronteira do conhecimento e tem seus títulos de nobreza amplamente reconhecidos, ainda que sem gerar diretamente procedimentos e tecnologias. Compreende-se então que na formatação da Agenda Nacional da Pesquisa, além de incorporar os INCTs e o CEPIDs, o Plano endossou a criação dos Centros de Excelência em Humanidades, com a vocação de pensar o país e o mundo ${ }^{25}$.

Já o aperfeiçoamento da avaliação e sua expansão para outros segmentos do sistema de CT\&I, consistiu na manutenção dos parâmetros em vigor desde o plano anterior, como a inclusão social e a nucleação (impacto dos programas à luz de sua capacidade de influenciar outros centros e nuclear linhas de pesquisa e áreas de concentração, formando quadros e criando referências), assim como na introdução de novidades e recalibragens, levando a ajustes e inflexões. Entre os ajustes e as inflexões, além daqueles elementos diretamente ligados à avaliação, que comentaremos em seguida ao tratarmos das recomendações, estão a necessidade de reconhecer mais atentamente as diferentes culturas de áreas, como no caso das tecnológicas, em que em regra muito mais vale um experimento, um engenho e um design inovadores do que meia dúzia de papers e demonstrações teóricas. Outra inflexão importante está na defesa doutrinal e programática da primazia da qualidade sobre a quantidade, levando negativamente ao combate do produtivismo e do taylorismo, e positivamente à criação de ambientes mais cooperativos e menos estressados.

Por seu turno, uma das estrelas maiores do sexto Plano, a priorização da multi e da interdisciplinaridade entre as principais características da pós-graduação e de importantes temas de pesquisa, não faz senão reconhecer os méritos da própria área no sistema da CAPES, que soube como poucas se impor e se legitimar, tendo sido aquela que mais cresceu nos últimos tempos, e também aquela que mais recusou propostas de criação de cursos novos. Além do mais, a priorização se justifica em razão da própria dinâmica da pesquisa e do conhecimento em escala mundial, levando instituições tradicionais no primeiro mundo a adotar procedimentos ousados na montagem de equipes de trabalho, juntando médicos, engenheiros e outros profissionais, bem como a implantar propostas revolucionárias em experiências curriculares. Tais foram os casos de Harvard, do MIT e da École de Science Politique, a famosa Science Po de Paris, que inseriu artes no currículo, com destaque para fotografia, com vistas a melhor educar as mentes e os corações dos 
estudantes, em busca de novas sensibilidades e inesperadas sinergias. No caso brasileiro, a priorização da pós-graduação multi e interdisciplinar levará à busca de novas referências cruzadas e eixos transversais da vida nas metrópoles, da produção de alimentos usando tecnologias limpas, dos diferentes biomas, da biologia marinha e das neurociências, a exemplo do PhD Program in Neural Computation da Universidade de Cornell, nos Estados Unidos. O mote é a frase de Popper segundo a qual "[...] 'Não estudamos temas, senãoproblemas'; e os problemas podem atravessar os limites de qualquer objeto de estudo ou disciplina [...]"26. Fiéis não à letra, mas ao espírito do texto do filósofo da ciência austríaco, em nossa proposta trocamos os temas pelos objetos disciplinares, e buscamos o locus do multi e do interdisciplinar tanto nos temas quanto nos problemas, como no tema ou no problema da água.

Finalmente, a priorização, no quinto eixo, da educação básica e de outros níveis e modalidades de ensino, especialmente do ensino médio, dispensa maiores explicações e já foi elucidada: trata-se de uma ação emergencial, justificada pelo apagão do sistema de ensino nos níveis fundamental e médio.

Junto com os eixos, com suas amplitudes e demarcações, o Plano propôs uma série de ênfases, abarcando prioridades e induções estratégicas, as quais irão repercutir nas recomendações. Trata-se, a bem da verdade, de um conjunto de políticas em nível macro, que por si só não define linhas e grupos de pesquisa, mas a intenção do governo e da CAPES de apoiá-los. Porém, tais ênfases e prioridades deverão ser interpretadas e trabalhadas pelos programas de pós-graduação, uma vez que a agência não tem o poder de impô-los, cabendo a decisão às IES em sua autonomia.

Feita a ressalva, os capítulos 9 e 10 apresentam as ênfases e as prioridades, nas perspectivas empresarial (cap. 9, p. 193, último parágrafo, no qual o leitor encontrará uma lista daquelas áreas e setores particularmente sensíveis ao mundo empresarial) e pública (cap. 10, já mencionado).

Como é sabido, os números e as estatísticas disponíveis mostram que a relação entre a pós-graduação e o setor empresarial é por demais frouxa, revelando nossa profunda indigência em converter ciência em tecnologia. Assim, apesar de o Brasil ser responsável por mais de $2 \%$ da produção científica mundial, o percentual de patentes brasileiras registradas nos Estados Unidos é ainda muito pequeno. Em 2008, de acordo com o USPTO, os EUA depositaram 257.818 pedidos de patentes, enquanto o 
Brasil registrou apenas 499 pedidos. No período 1980-2003, a participação de publicações brasileiras no mundo cresceu de $0,4 \%$ para $1,8 \%$, enquanto a participação de patentes brasileiras ficou praticamente constante abaixo de $0,1 \%$.

Quanto ao setor público e às ações do governo, na Introdução ao cap. 10, o leitor encontrará o fundamento dessas ênfases e prioridades, consubstanciadas na convicção de que

[...] nas próximas décadas o mundo enfrentará uma série de desafios, dentre os quais podemos destacar como mais relevantes as questões que cercam a geração de distribuição de energia, a produção de alimentos, o uso racional e a distribuição da água, a universalização da saúde, a sustentabilidade do meio ambiente e a redução dos conflitos sociais ${ }^{27}$.

Conforme salientamos, além de políticas públicas adequadas, o enfrentamento desses desafios não poderá consumar-se sem o uso intenso e inteligente de ciência e tecnologia. Para tanto, em razão dos gaps e dos déficits, um grande esforço deverá ser feito com vistas a preparar quadros e elevar o nível educacional da população. Feito isso, no cenário que se apresenta para os próximos dez anos, o país poderia estar preparado para implementar políticas e atingir um nível de desenvolvimento desejável

[...] nas áreas de energia, crescimento populacional nas metrópoles, preservação do meio ambiente, defesa, monitoramento e controle do espaço aéreo e de nossas fronteiras terrestres e marítimas, desenvolvimento de transporte eficiente de pessoas e cargas, ampliação e melhoria da produção de alimentos, monitoramento e previsão de fenômenos meteorológicos extremos, uso e preservação dos recursos hídricos, exploração sustentável da biodiversidade e desenvolvimento de produtos e serviços nas áreas com pouco desenvolvimento no Brasil atual ${ }^{28}$.

O leitor interessado em obter mais informações poderá consultar o conjunto do capítulo, no qual encontrará uma análise bastante pormenorizada desses grandes temas nacionais, como o tema da energia, abarcando petróleo e gás natural, hidroelétricas, termoelétricas, energia nuclear, energia solar, energia fotovoltaica, energia eólica, álcool e biomassa.

Esta listagem de áreas de interesse nacional por si só não define nem políticas públicas nem programas e linhas de pesquisa de pós-graduação, mas indica ênfases e prioridades que, reunidas e consolidadas, darão 
lugar a metas. Uma meta importante formulada pelo Plano consiste na ampliação do parque nacional de pós-graduação ${ }^{29}$. Junto com ela aparecerão outras, exigindo sua recalibragem: assim, a interiorização do SNPG, o espalhamento não linear do sistema, a equalização das oportunidades e o seu reverso (combate às assimetrias e desigualdades, das regiões e das áreas do conhecimento), a criação de centros de excelência em ensino e pesquisa de padrão internacional, etc. ${ }^{30}$. À vista disso, o Plano definiu as seguintes diretrizes que deverão ser observadas, implementadas por ações específicas e induzidas, e definidas pelos governos e a comunidade:

- estímulo à formação de redes de pesquisa e pós-graduação, envolvendo parecerias, nacionais e internacionais, no nível da fronteira do conhecimento, com vistas à descoberta do 'novo' e do inédito;

- ênfase nas questões ambientais, associadas à busca do desenvolvimento sustentável e do uso de tecnologias limpas;

- garantia do apoio ao crescimento inercial do SNPG, favorecendo não obstante o uso de parcelas significativas do orçamento das agências como instrumento de implantação de políticas inovadoras;

- consideração, nos diferentes programas visando ao desenvolvimento, economia, saúde e educação no Brasil, das características culturais da população-alvo; e

- atenção às atuais gerações de crianças e jovens, particularmente nas áreas de saúde e educação em ações voltadas para o ensino básico e superior com a participação da pós-graduação, pois dependerá dessas gerações o desempenho da economia brasileira nas próximas décadas, como membros da população em idade ativa, em um contexto de rápido crescimento, em termos absolutos e relativos, e de forte aumento da população idosa ${ }^{31}$.

Tais são, portanto, as cinco diretrizes gerais do sexto PNPG. A elas soma-se um conjunto de diretrizes específicas, totalizando dez ações consideradas estratégicas, várias delas desdobradas em ações e objetivos específicos que não vem ao caso analisá-las aqui, podendo o leitor interessado reportar-se ao fim do vol. $1^{32}$.

\section{CONCLUSÃO}

Nossa expectativa, depois de ver o Plano aprovado pelo Conselho Superior da CAPES e chancelado pela Presidência da República, é acompanhar a sua transformação em política de Estado e matéria de política pública, 
resultando em ações estratégicas consistentes com as necessidades do país e em programas de ensino e pesquisa condizentes com o estado da arte do conhecimento em nível mundial. Passado quase um ano, ainda na espera dos primeiros resultados, nossa convicção é de que o PNPG fez o diagnóstico certo e propôs as medidas adequadas; porém, quem fez o Plano não tem o poder de executá-lo, nem mesmo a Agência que o encomendou, podendo muito bem os dois volumes dormir nas prateleiras das repartições em Brasília e em outras paragens. Assim, o sucesso ou o fracasso do sexto PNPG, a exemplo dos outros, dependerá de sua capacidade de atrair ou não a comunidade acadêmica e a sociedade civil organizada. Em todas as esferas da ação humana, o fracasso está emparelhado com o êxito, e não depende inteiramente das ações e intenções dos indivíduos. A favor do fracasso do Plano conta a entropia dos brasileiros, anárquicos renitentes e refratários a todo tipo de planejamento. A favor do sucesso conta o poder organizador e a força coercitiva do Estado e seus órgãos; contudo, nada será feito se não houver decisão política e a adesão de amplos segmentos da sociedade. Havendo as duas coisas, poderemos vencer o voluntarismo, o mandonismo e a cultura da improvisação - esta é a esperança. Então, fincado num ambiente mais favorável, o Plano com a nossa ajuda descerá das prateleiras, servirá de guia para as ações e poderá converter-se em realidade, tendo dez anos pela frente.

O sexto Plano propõe o crescimento do sistema, mas não o crescimento linear de todas as áreas: é necessário escolher, crescer com qualidade, combater as assimetrias e as distorções, e vencer o conservadorismo do sistema. O lema é: ousar mais, experimentar o novo, atentar aos desafios e enfrentar as urgências.

Uma das urgências é vencer o grave déficit de cultura de inovação que atinge o empresariado nacional e a universidade brasileira, resultando em nossa dificuldade secular de transformar ciência em tecnologia, cujo sinal mais evidente é a nossa indigência em patentes. O Plano deu então a diretriz de combater o déficit e propôs o modelo da tríplice hélice. Espera-se então que a cultura da inovação ganhe cidadania entre nós nos próximos dez anos. Mas não nos iludamos: que ninguém aguarde uma nova Stanford com suas 6000 empresas incubadas aqui nos trópicos; está em jogo abrir o caminho, e começar bem, como dizia Aristóteles, é ter mais da metade do caminho andado. 
No modelo da tríplice hélice, está reservado às engenharias um papel de grande relevo, junto com as biotecnologias e as tecnologias agrárias. O plano reconhece a necessidade de apoiá-las, especialmente as engenharias, e o governo decidiu que irá priorizá-las no programa Ciência sem fronteiras - o que, sem dúvida, é muito bom. Mas qual engenharia ou quais engenharias? Não está claro. Parece que tudo foi feito rápido demais, depois que o governo Dilma se viu desafiado por Obama, que em sua visita ao Brasil em 2011 instou-o a enviar mais estudantes às universidades americanas. Na verdade, considerados todos os aspectos, a situação das engenharias não é de apagão, nem de gargalo. Os números do próprio governo mostram isso. Se a demanda por engenheiros aumentou bastante após décadas de estagnação, estudos do MEC mostram que os concluintes em engenharia aumentaram 129\% no período 2000-2009. Por sua vez, um levantamento recente do IPEA estima que, mantida a taxa de crescimento da economia da ordem de 3,5\%, como ocorreu na última década, o número de engenheiros formados será suficiente para as necessidades do país. De fato, pode-se dizer, o Brasil não está formando menos ou piores engenheiros; por outros motivos, os Estados Unidos estão sofrendo escassez desses quadros, porém não um déficit de cultura de inovação; mas, lá como aqui, há problemas de estrutura e de conjuntura, exigindo ajustes permanentes na formação de quadros especializados. E no caso brasileiro, persiste a pergunta: quais áreas da engenharia deverão ser incentivadas ou consideradas prioritárias? Certamente o mercado é elástico e os cursos de engenharia são flexíveis e saberão adaptar-se aos novos contextos e ambientes. Resta saber o que fazer com a oferta expressiva de novos engenheiros nos anos que virão, e como está sendo planejado, se a tendência à desindustrialização da economia brasileira se efetiva, como temem os economistas.

Sobre o programa Ciência sem fronteiras, aliás, é oportuno expressar nossa perplexidade diante da proposta do governo. Conforme aparece no capítulo final - Conclusões e recomendações, o sexto PNPG recomenda um significativo aumento do envio de estudantes ao exterior para realizar doutorado pleno. Não se trata de enviar qualquer um, nem aos montes, mas de enviar um bom contingente dos melhores. E o que é importante: de todas as áreas do conhecimento, numa indução estratégica para arejar as instituições e para capturar o conhecimento novo, no estado da arte. Agora, contrariando o Plano que acabou de aprovar, o governo decide 
que vai enviar ao exterior 100.000 estudantes, não de todas as áreas, mas das tecnológicas e das ciências, ficando de fora as humanidades. Azar das ciências naturais e das áreas tecnológicas, que vão correr o risco de perder seus cérebros e ver seus cursos esvaziados, depois de décadas de esforço - a mensagem passada é que elas fracassaram, não tendo criado profissionais para atender às necessidades do país, nem gerado patentes e outras modalidades de propriedade intelectual. Sorte e azar das ciências humanas e das humanidades: sorte, porque os cursos seguirão intactos; azar, porque ninguém vai sair mais - só os estudantes de arquitetura que vão estudar design.

Vamos ver depois o que vai acontecer. As ações dos governos, por mais poderosas que sejam e impulsionadas por essa espécie de energia que é o dinheiro, dependem de outros agentes humanos, dos jogos de pressão e contrapressão, e podem ser desviadas ou interrompidas. O Plano, por sua vez, não passa de um guia e um caminho. Fruto dele ou não, mas tendo a CAPES como parceira, e a CAPES um tanto somos nós, o SNPG é celebrado como a única coisa que deu certo nesse país em que a educação vive um verdadeiro apagão nos dois primeiros níveis de ensino. Todavia, muita coisa há de ser feita ainda na pós-graduação e no ensino superior.

No Brasil, como é sabido, há aulas demais, e pesquisas de menos. Na pesquisa, o taylorismo campeia e levou ao triunfo da quantidade sobre a qualidade. Como se sabe, não só nas ciências e engenharias, mas na educação e pedagogia prevalecem nos currículos aquilo “[...] que é fácil de ser medido com provas e o que funciona com aula expositiva [...]”. Para piorar a situação, no tocante aos conteúdos e às matérias ensinadas, "Os alunos nunca fazem ciência ou engenharia de verdade, nunca se aventuram em descobrir algo novo ou resolver um problema real; aprendem só o 'básico', que em grande parte ignora os avanços científicos dos últimos 50 anos.”. Resultado: sem base científica adequada e sem ambiente apropriado para a experimentação e a criatividade, “[...] as vítimas são a ciência e a tecnologia, que só são devidamente aprendidas quando os alunos trabalham em projetos, fora da aula tradicional" ${ }^{\prime 3}$.

Pensamos que podemos sumariar todas essas considerações importantes sobre o processo do conhecimento relacionado com o ensino e a aprendizagem num diagrama com três eixos ortogonais, conforme mostra a Figura 7:X = eixo da imitação, onde tudo começa e para onde tudo volta, 
fundada em observações acuradas que mimetizam as coisas; $\mathrm{Y}=$ eixo da incrementação ou da expansão contínua, associado ao alargamento das observações e à sua extensão a outros domínios do real, resultando em conhecimento novo incremental, mas não no revolucionamento das áreas; $Z$ = eixo da criação, consistindo em invenções do novo e em descobertas desestabilizadoras, e como tal comum às artes, às engenharias e às ciências.

Se cada universidade brasileira for representada por um ponto nesse gráfico tridimensional, o que se verifica é que muitos pontos estarão no eixo OX (como o ponto verde claro), alguns poucos no plano XY (como o ponto azul escuro) e pouquíssimos no espaço XYZ (como o ponto azul claro), e mesmo assim com valores $\mathrm{Z}$ muito próximos do plano XY.

Ou seja, no Brasil prevalece o ensino da imitação, enquanto a pesquisa - a pouca que há e que foi além da imitação - está estacionada no eixo da incrementação, de modo que todo o esforço a ser feito, nos anos que virão, é justamente passar para o espaço de 3 dimensões, fazendo aparecer a coordenada da criação (eixo OZ), quando deixaremos de ser um país meramente consumidor e difusor de C\&T, e passaremos a ser produtor e criador, criando as condições para pôr o I na grande equação do conhecimento: CT\&I.

Foi pensando nessas coisas que propusemos o modelo humboldtiano (SOARES, 2008) como o grande paradigma do sexto PNPG. Hoje, mais distanciados, levando em conta experiências como a do MIT (inovação tecnológica numa perspectiva regional: desenvolver o Estado de Massachusetts)

Figura 7

\section{Eixos de criação, imitação e incrementação}

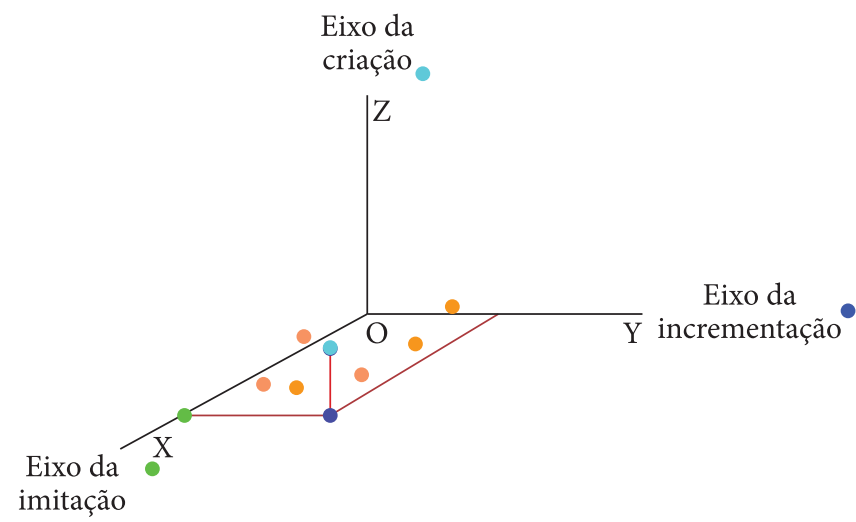


e outras, entendemos que de fato trata-se do modelo neo-humboldtiano. Isto é, fundado na aliança do ensino e da pesquisa, como no tradicional, e abrindo-se ao modelo da tríplice hélice, ao instalar a parceria universidade/ governo/empresa ou outras instituições da sociedade, com a consequente justificativa da inclusão do prefixo "neo". Trata-se, como em qualquer modelo, de uma construção ideal ou de um constructo mental e, como no caso dos modelos das ações humanas, de uma construção com um forte componente prescritivo que leva à primazia do dever-ser ideal e normativo sobre o ser concreto e real. Quer dizer, nas duas acepções do termo, em razão dos déficits do real, alguma coisa como uma utopia e um estado ótimo, não algo concreto ou a realidade efetiva. Por isso, ao propor o modelo neo-humboldtiano para as nossas universidades, não queremos dizer que ele exista em sua plenitude em nossos meios, menos ainda o humboldtiano tradicional. Simplesmente, a sua validade não depende de sua existência real; mas tão só do fato que ele seja visto como um ícone, uma bússola ou até mesmo, se morássemos no hemisfério norte, como a estrela polar, ou, no hemisfério sul, como o Cruzeiro do Sul, capaz de guiar a mente e mostrar o caminho. E em especial, para aquelas poucas universidades públicas que estão fundadas na aliança do ensino e da pesquisa, fazendo da inovação o transbordamento da criação e da própria universidade. 


\section{REFERÊNCIAS}

BLIKSTEIN, P. Uma nova concepção para ensinar exatas. Folha de São Paulo, São Paulo, p. 3, 25 set. 2011.

COORDENAÇÃO DE APERFEIÇOAMENTO DE PESSOAL DE NÍVEL SUPERIOR - CAPES. Plano nacional de pós-graduação [PNPG] 2011-2020. Brasília: CAPES, 2010. v. 1.

GIBBONS, M. et al. The New Production of Knowledge: The Dynamics of Science and Research in Contemporary Societies. London: Sage, 1994.

SOARES, A. G. T. O conceito de universidade no projeto da UNICAMP. Campinas: Editora da UNICAMP, 2008. O livro contém dois anexos, um deles com o estudo original de Wilhelm von Humboldt que serviu de base para a fundação da Universidade de Berlim, acompanhado da sua tradução portuguesa por Fausto Castilho e intitulada "Sobre a organização interna externa dos estabelecimentos científicos superiores em Berlim”.

\section{NOTAS}

${ }^{1}$ Ao longo do artigo, o leitor encontrará um conjunto de referências sobre o Plano Nacional de Pós-Graduação 2011-2020 recentemente publicado pela CAPES ao comemorar seus 60 anos e editado em dois volumes, ambos com data de 2010. O primeiro volume abriga uma série de capítulos de natureza teórico-conceitual bem como pragmático-política, resultando em recomendações e diretrizes para o conjunto do sistema e tendo como horizonte o próximo decênio. O segundo volume abarca dezenas de documentos elaborados por especialistas e convidados, além de membros de Diretorias da CAPES e da Comissão Nacional responsável pelo Plano. Tendo recebido a chancela presidencial no início de 2011, o PNPG segue agora o seu caminho normal no Congresso e, uma vez aprovado, integrará a peça maior do Plano Nacional de Educação, de responsabilidade do MEC e igualmente em processo de tramitação. Os dois volumes que serviram de referência ao presente artigo, especialmente o primeiro, podem ser considerados, portanto, documentos oficiais, e a este título submetidos ao crivo da comunidade acadêmica, como no nosso caso. E o fazemos, nós, os dois autores, na dupla condição de Coordenador Geral do PNPG (Francisco César de Sá Barreto, ex-reitor da UFMG e prof. Emérito da UFMG -Departamento de Física) e membro da Comissão Coordenadora (Ivan Domingues, prof. Titular da UFMG - Departamento de Filosofia).

${ }^{2}$ COORDENAÇÃO DE APERFEIÇOAMENTO DE PESSOAL DE NÍVEL SUPERIOR

- CAPES. Plano nacional de pós-graduação [PNPG] 2011-2020. Brasília: CAPES, 2010. v. 1.

3 Ib., p. 15.
${ }^{4}$ Ib., p. 15.
${ }^{5}$ Ib., p. 15. 
${ }^{6}$ Ib., p. $15-16$.

7 Ib., p. 16.

8 Ib., p. 17.

9 Ib., p. 18-19.

10 Ib., p. 186.

11 BLIKSTEIN, P. Uma nova concepção para ensinar exatas. Folha de São Paulo, São Paulo, p. 3, 25 set. 2011. Evidentemente, tal afirmação não pode ser universalizada, mas revela uma tendência importante nas engenharias, sobretudo aquelas ligadas à aeronáutica, à indústria automobilística e à informática. Há, no entanto, outros segmentos que exigem cálculo apenas, ou mais matemática e menos design, como engenharia elétrica, nuclear, ambiental e nanomateriais (têm algum design). Não obstante, a presença cada vez maior do design nos engenhos e artefatos tecnológicos é um fato importante, tendo mudado o rumo da história da engenharia.

12 PNPG, op. cit., p. 299.

13 Ib., p. 191.

14 Ib., p. 191.

15 Ib., p. 191.

16 Ver no PNPG, vol. 1, p. 44, os dados de 2008.

17 Ib., p. 249.

18 Para a lista completa, ver p. 193.

19 Para mais detalhes, ver p. 221.

20 Cf. COORDENAÇÃO DE APERFEIÇOAMENTO DE PESSOAL DE NÍVEL SUPERIOR, p. 158.

21 Ib., p. 15.

22 Ib., p. 294.

23 Ib., p. 20.

24 Ib, p. 20.

25 Ib., p. 21, 297.

26 Ib., p. 137.

27 Ib., p. 195.

28 Ib., p. 195.

29 Ib., p. 293.

30 Ib., p. 293. 
31 Ib., p. 294.

32 Ib., p. 296-305.

33 Todas as citações do parágrafo foram retiradas de Blikstein (2011), art. cit, p. 3.

Recebido: 15/03/2012

Aprovado: 15/05/2012

Contato:

Universidade Federal de Minas Gerais Instituto de Ciências Exatas, Departamento de Física Avenida Antônio Carlos, 6627

CEP $31270-901$

Belo Horizonte, MG

Brasil 